

\title{
COMPUTATIONAL SIMULATION AND EVALUATION OF THE USE OF COOKING OIL FOR BIODIESEL GENERATION IN MUNICIPALITIES OF SOUTHERN BRAZIL
}

\author{
SIMULAÇÃO COMPUTACIONAL E AVALIAÇÃO DO USO DE ÓLEO DE COZINHA PARA \\ GERAÇÃO DE BIODIESEL EM MUNICÍPIOS DO SUL DO BRASIL
}

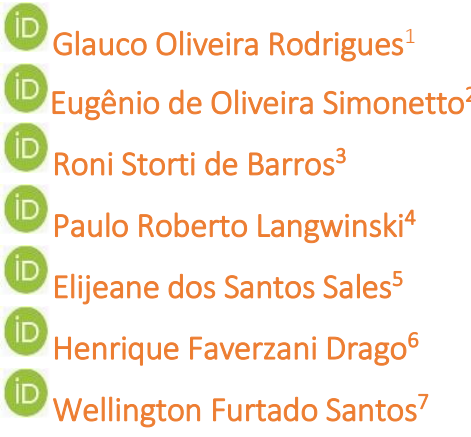

1 Mestre em Administração Universidade Federal de Santa Maria - UFSM. Santa Maria, Rio Grande do Sul - Brasil. glaucop10@redes.ufsm.br

2 Doutor em Administração Universidade Federal de Santa Maria - UFSM Santa Maria, Rio Grande do Sul - Brasil. eosimonetto@gmail.com

${ }^{3}$ Mestre em Administração Universidade Federal de Santa Maria - UFSM. Santa Maria, Rio Grande do Sul - Brasil. ronistt@gmail.com

${ }^{4}$ Mestre em Administração Universidade Federal de Santa Maria - UFSM. Santa Maria, Rio Grande do Sul - Brasil. langwinski@gmail.com

${ }^{5}$ Mestre em Administração Instituto Federal Farroupilha - IFF. Uruguaiana, Rio Grande do Sul - Brasil. elijeanesales@gmail.com

${ }^{6}$ Mestre em Administração Universidade Federal de Santa Maria - UFSM. Santa Maria, Rio Grande do Sul - Brasil. henrique_fd@yahoo.com.br

7 Doutor em Administração Instituto Federal Farroupilha - IFF. São Vicente do Sul, Rio Grande do Sul - Brasil. wellington.furtado@gmail.com

Recebido em: 04 fev. 2020

Aprovado em: 13 jun. 2020
Resumo: O presente trabalho tem como objetivo desenvolver e avaliar uma proposta de submodelos de simulação computacional para avaliar o uso de óleo de cozinha na geração de biodiesel a ser utilizado em caminhões de coleta seletiva em alguns municípios da região central do Rio Grande do Sul. Para o desenvolvimento dos modelos, foi utilizado o método System Dynamics. Matematicamente, um modelo System Dynamics é um sistema de equações lineares. Em geral, este sistema é muito complexo para ser resolvido analiticamente, então a integração numérica é usada. Por meio do Vensim, foi possível desenvolver, documentar, simular e analisar os modelos, observando os impactos ambientais e sociais causados pela coleta nos sete municípios estudados. Em relação à implementação no simulador Vensim, foram utilizados dados históricos para verificar a integração entre os módulos componentes do modelo, bem como os resultados gerados, uma vez que foram avaliados os outputs produzidos pelo modelo de simulação a partir de dados reais a eles fornecidos. Os resultados foram satisfatórios e atenderam às expectativas dos designers.

Palavras-chave: Biodiesel. Dinâmica de sistemas. Modelagem computacional. Vensim.

Abstract: The present work aims to develop and evaluate a proposal of computational simulation submodels to evaluate the use of cooking oil in biodiesel generation to be used in selective waste collection trucks in some municipalities of the central region of Rio Grande do Sul. For the development of the models, the System Dynamics method was used. Mathematically, a System Dynamics model is a system of linear equations. In general, this system is too complex to be analytically solved, so numerical integration is used. Through Vensim, it was possible to develop, document, simulate and analyze the models, noting the environmental and social impact caused by the collection in the seven municipalities studied. Regarding the implementation in the Vensim simulator, historical data were used to verify the integration between the model component modules, as well as the results generated, since the outputs produced by the simulation model from real data provided to them were evaluated. The results were satisfactory and met the designers' expectations.

Keywords: Biodiesel. Systems dynamics. Computational modeling. Vensim. 


\section{Introduction}

The increasing climate changes of the planet related to deforestation and carbon monoxide emissions into the atmosphere have attracted the attention of scholars worldwide (LAM, 2010; MASJUKI, 2011; NIJMEIJER et al., 2018; SHIMABUKURO et al., 2019; KUMAR; SCHEITER, 2019; MARCOSMARTINEZ et al., 2019). In this context, one of the main causes of this weather is the high use of fossil fuels such as petroleum (CHEN; CHEN,2019; BHATIA et al., 2019).

Due to the dependence and high consumption of this fuel, problems such as global warming, increased pollution of the oceans caused by constant oil spills (ASHOK et al., 2019; AMIR-HEIDARI et al., 2019; YE et al. ., 2019) and even air pollution in large cities, because the burning of oil products through their combustion in automotive engines, bring up discussions about solutions to reduce their use (SANTOS; SILVA, 2016).

Large industries, both national and international, have been looking for ways to reduce environmental polluters. The application of sustainability policies is an excellent tool for public awareness, so people begin to rethink their attitudes towards the environment (FREITAS et al, 2010).

In the face of this view searching for alternatives to reduce environmental pollution, there are several initiatives to extend the life cycle of different environmentally harmful wastes. Productive sectors such as Urban Solid Waste collection seek ways not only in the face of economic appeal, but especially to mitigate the effects of environmental degradation and air pollution (FERRONATO et al., 2019).

In this concern, Leite (2007) presents biodiesel as an alternative for clean energy. In this new century, biodiesel has advanced space as an option for use in diesel engines. This attitude can help increase farm household incomes, reduce greenhouse gas emissions and is still a viable solution to many countries' dependence on oil (SOUZA et al, 2016).

There are different forms of biodiesel production, which can use algae (SHOMAL et al., 2019), seeds (ANWAR et al., 2019) as well as "post-use" cooking oil (AGHEL et al., 2019). Based on the factors that most contribute to this mode of production, it is the correct destination of these oils, considering that their disposal is often performed in inappropriate places, causing damage to nature (RODRIGUES et al, 2016).

Several researches have analyzed the use of cooking oil in biodiesel production (BECHETet al., 2010; DEMIRBAS, 2009; MENDES, 2015; ZANG AND KONG, 2010; NABI et al., 2019; VELMURUGAN et al., 2019; TAN et al., 2019; MOHADESI et al., 2019; ATABANI et al., 2019). In Brazil, Santos e Silva (2016) advocate its use in the motor vehicle fleet, as in addition to avoiding its improper disposal, it would also reduce the emission of greenhouse gases in the atmosphere, such as carbon dioxide and sulfur (main sources acid rain). 
The world energy matrix is still predominantly composed of fossil fuels, such as diesel oil (CRUZ; FERREIRA; RODRIGUES, 2017). The high consumption of this fuel can cause to the exhaustion of this energy matrix, resulting in serious problems in the world economy (SHAFIEE and TOPAL, 2009; MANDOTRA; AHLUWALIA; RAMTEKE, 2019; ZHAO et al., 2019; LU et al., 2019). Thus, the search for fuels from renewable sources has gained prominence in recent years. Among them is Biodiesel, characterized by ANP (2015) as a fuel produced from vegetable oils or animal fats.

The Biodiesel must observe the specification established by ANP Resolution No. 7/2008 and, in order to be compatible with diesel engines, vegetable oil must go through a chemical process called transesterification, carried out in biodiesel production facilities authorized by the National Agency of Petroleum (ANP) (ANP, 2015).

To reuse post-use cooking oil and transform it into raw material for biodiesel production, the BIOBOT20 processor is used. This equipment helps small producers refine excess vegetable oils in fatty acid methyl esters through a conversion process known as transesterification. Compared to diesel, biodiesel is a great alternative to becoming independent of the fossil fuel industry and having transportation in its own hands.

Another way to generate biodiesel from cooking oil is through the use of a small plant. According to Vedana (2006), a project to build a small biodiesel plant is the same as that of a large plant. In both cases, the maximum biodiesel yield per unit of oil should be sought, in addition to producing with High market quality.

In this context, this research aims to develop and evaluate a proposal for computer simulation submodels to evaluate the use of cooking oil in the generation of biodiesel to be used in selective collection trucks in some municipalities in the central region of the state of Rio Grande do Sul. An economic feasibility study will be carried out, simulating the purchase of biodiesel directly from the concessionaires or producing biodiesel from the reuse of "post-use" cooking oil. For this, simulations will be performed using the BIOBOT20 processor in a small plant. After the simulation, it will be analyzed which scenario is most interesting for the study partner company.

To meet the objective, the research was divided into five stages. Initially exploratory research was carried out. The second stage presents the development of the solution, through the construction of formal models capable of representing the problem (definition of variables and their relationships). The computational implementation of the solution (step (III)), will be performed with the aid of the Vensim simulator (VENTANA SYSTEMS, 2016) from the Systems Dynamics area. Step (IV) is responsible for the verification and validation ( $v \& v$ ) of the solution, through laboratory tests and analysis of historical behavior (with the data that were possible), to verify whether the results obtained represent part of the observed reality, as well as through the simulation of an experiment using nine scenarios for that. Managers from the areas involved were also interviewed to ensure greater reliability of the study. 
Finally, the research will be analyzed in step $(V)$ where the differences between the existing possibilities will be exposed.

The chosen methodology [and related to systemic thinking, called system dynamics, which seeks to study the structures of organizational and social systems through the representation of causal relationships between its elements and the study of their evolution over time.

In relation to the structure, after this introductory chapter the research method is presented. Then there is the theoretical framework. In the sequence is a description of the development of the model and experiment and later, concludes with final considerations followed by recommendations for future researches.

\section{Theoretical reference}

\subsection{Biodiesel}

Biodiesel is seen by many researchers as a source of secular energy that has recently grown (Mendes, 2015; Bórawski et al., 2019). Despite the existence of several technologies related to the generation of clean energy, biodiesel has been shown as one of the most important alternatives, considering its economic, social and environmental impact (VIDMANTAS et al, 2010). In Brazil, according to Mendes (2015), its production and consumption would prove to be a strong social motivator in less favored areas, as several inputs could adapt to the climatic and vegetation conditions of the Brazilian semiarid, becoming a source of income for the population. these regions.

Tavares and Da Silva (2008) define biodiesel as a natural fuel used in diesel engines, obtained from vegetable or animal raw materials. Vegetable raw materials are derived from vegetable oils, such as soybean, castor, palm (palm), sunflower, jatropha, peanuts, among others. In Brazil, according to Law No. 11,097 of September 13,2005 , it is a renewable biomass derivative for use in internal combustion engines with compression ignition or for the generation of other energy, which may partially replace or totally the fossil fuel. It is obtained through processes such as cracking, esterification, or transesterification - the latter being the most used process for its production. For the purposes of this study, biodiesel can be understood as a renewable fuel derived from vegetable oils or animal fat, used in diesel engines, produced by glycerine removal, which occurs through chemical processes.

According to Mendes (2015), the concept of biodiesel adopted by the Natural Agency of Petroleum, Natural Gas and Biofuels (ANP), is a natural fuel used in diesel engines, produced from renewable sources and that meets the specifications of ANP Resolution no. 14 of May 11, 2011. ANP defines biodiesel as a fuel composed of long chain fatty acid alkyl esters derived from vegetable oils or animal fats, as specified in Technical Regulation ANP No. 4 of 2012, Annex to ANP Resolution No. 14/2012 (BRAZIL, 2008). Research conducted by SEBRAE in 2008 points to biodiesel as a biodegradable 
fuel derived from renewable sources, which can be obtained by different processes such as cracking, esterification or transesterification.

Secular fuel (biodiesel) is an alternative to petroleum-derived fuels (since it emits less polluting gases) and has been tested in countries such as Argentina, the United States, Malaysia, Germany, France, among others (TAVARES; DA SILVA, 2008; ZAILANI et al., 2019). It has viscosity and combustion characteristics similar to petroleum diesel. These characteristics are acquired through the chemical reaction between triglycerides or fatty acids and a small carbon chain alcohol (usually methanol or ethanol). Pure biodiesel is also called B100. Biodiesel blends with mineral diesel are called "BXX" (where "XX" refers to the amount of biodiesel in the blend). For example, B10 refers to a mixture that contains $10 \%$ biodiesel and $90 \%$ mineral diesel.

According to Mendes (2015), biodiesel production is mainly carried out by vegetable oils available internally in producing countries, most of which are in excess of the food industry. Several studies have analyzed the use of cooking oil in biodiesel production (Bechetet al., 2010; Demirbas, 2009; Mendes, 2015; Zang and Kong, 2010; KANNENGIESSER et al., 2016; ABOELAZAYEM; GADALLA; SAHA, 2019; AGHEL et al., 2019; AHMAD et al., 2019; NABI et al., 2019; VELMURUGAN et al., 2019; TAN et al., 2019; MOHADESI et al., 2019). More details on this production mode will be explained in the following session.

\subsubsection{Biodiesel from recycled cooking oil}

Biodiesel is usually referred to as "the fuel of the future" because it is biodegradable and nontoxic, with properties similar to diesel. Biofuels are derived from renewable resources and widely used as transport fuels (MADHESHIYA; VEDRTNAM, 2018). In this regard, research has pointed to the need for new energy sources as an alternative to the use of fossil fuels. Vehicle emissions such as CO, HC and SOx are extremely harmful and lead to the need for a safer, more economical alternative fuel than petroleum-based diesel (RANJAN, et al.; 2018). The environmental benefits from emissions from the use of biodiesel in engines, as opposed to those from petroleum diesel, are evident. Biodiesel is sulfur free, non toxic and biodegradable. Reduces gaseous pollutant emissions, reduces global warming, is economically competitive and can be produced by small businesses (MIRANDA, et al.; 2018; KUMAR et al., 2018; CHRYSIKOU et al., 2019).

A variety of oils can be used to produce biodiesel. However, the efficiency of raw material yield per unit area has affected the viability of raising production to the industrial levels needed to supply the automotive market. The National Petroleum Agency (ANP) is the organization that regulates the use of biodiesel in fuel oil throughout Brazil. Current laws have required that as of 2017, diesel oil should 
contain 8\% biodiesel (ie B8). In some Brazilian regions, bus fleets already use the B20 (20\% biodiesel) mixture as fuel (MIRANDA, et al.; 2018).

Concerning to cooking oils, studies have deepened the viability of their reuse as biofuel after human consumption. Several substances have potential harmful to the environment; And one of the most common used by everyone in everyday life is edible oil. Its use happens at both domestic and commercial levels (VIDMANTAS et al, 2010). According to Reis, Ellwanger and Fleck (2007), in Brazil, frying oil is normally discharged into the municipal sewage system, causing environmental impacts such as pollution of rain and sanitary networks. When mixed with organic matter, clogging of fat boxes and pipes occurs. In some cases, the pipes need toxic chemicals to solve the problem. If the sewage originated by mixing with the oil penetrates the soil, the water table will be contaminated, resulting in large amounts of water unfit for use (Reis and Ellanger, 2007). In addition, it can also represent a potential cause of human health problems (FELIZARDO, 2006). In this sense, the use of frying oil residues for biodiesel manufacturing reduces contamination problems, because its reuse can reduce the government's burden of disposing of waste, maintaining public sewage and treating petroleum wastewater (ENCINAR; et al, 2007). Thus, used cooking oils can be converted to biodiesel as a source of energy while reducing environmental pollution (SAHAR, et al., 2018).

The most important obstacle in the industrialization and commercialization of biodiesel is production costs. In the meantime, using recycled cooking oil can reduce biodiesel production costs by $60-90 \%$. This is because the price of recyclable cooking oil is two to three times cheaper than vegetable oils and also reduces the cost of waste removal and treatment (TALEBIAN-KIAKALAIEH; ABIM; MAZAHERI, 2013).

One of the main criteria for the quality of a biofuel is its storage stability. Vegetable oil derivatives can deteriorate due to hydrolytic and oxidative reactions (MITTELBACH; GANGL, 2001). According to Madheshiya and Vedrtnam (2018), biodiesel can be produced by dilution, microemulsion, pyrolysis and transesterification (alcohololysis). In this regard, according to Talebian-Kiakalaieh, Abim and Mazaheri (2003), there are two transesterification methods: (a) with catalyst and (b) without catalyst. Using different types of catalysts improves biodiesel rate and yield. The transesterification reaction is reversible and excess alcohol shifts the balance to the side of the product.

For Felizardo. (2006), the production of biodiesel from recycled frying oil is viable if performed through the basic catalyzed transesterification method. Biodiesel produced through this procedure has the necessary quality to be a substitute for diesel. In an effort to produce high quality biodiesel at lower costs, researchers are using new processes to decrease the reaction time, the amount of alcohol, the catalyst and particularly the reaction temperature (TALEBIAN-KIAKALAIEH; ABIM; MAZAHERI, 2013).

However, some important items need to be considered when using recycled frying oil in the biodiesel composition. As described by Encimar, González and Rodríguez-Reinares (2007), the high 
temperatures of typical cooking processes and food water accelerate triglyceride hydrolysis and increase the content of free fatty acids in the oil, impairing the quality and yield of biodiesel. . In addition, the use of recycled cooking oil-based biodiesel tends to increase fuel consumption compared to diesel.

Abed, et al (2018) observed in their study that biodiesel blends with recycled oil showed an increase in fuel consumption approximately proportional to the amount of biodiesel blended with diesel.

Nevertheless, recent concerns about sustainability costs, the environment and raw materials have made the use of waste oils attractive to industry, especially if stimulated with the economic benefits associated with the use of biodiesel blends, with a very good prospect for coming years (FELIZARDO, 2006; BÓRAWSKI et al., 2019).

\section{Research methodology}

In this article, the research method used to develop the computational model will be based on the methodology presented by Law (2015) on systems dynamics. The Systems Dynamics methodology, developed by Jay Forrester, in the 1950s, makes it possible to study the behavior of systems with respect to time, so it is a methodology that, when used, allows its users to evaluate the consequences of their decisions in a future time horizon (DAELLENBACH; MCNICKLE, 2005). For Geum, Lee \& Park (2014) systems dynamics is the combination of theories, methods and philosophies, aiming at analyzing the behavior of systems. For Bueno (2013), the systems dynamics is a method developed for the analysis of the cause and effect relationships of certain variables of a system, be it organizational or social.

According to Bueno (2013) the addition of information causes actions (flows), changing the state (level) of a system, when a period of time has elapsed, generating two types of feedback cycles: the negative (or equilibrium) - in which the system reacts to changes, compensating for them; and the positive (or self-reinforcing) - in which the system amplifies possible disturbances.

For Vaz and Maldonado (2016), the main premise of the dynamics of systems refers to the importance of the structure of the system, that is, the physical elements, the decision rules and their interrelations, to explain the behavior of the system under study. The second premise of the dynamics of systems, according to the authors mentioned above, is related to the system's responses to the actions of decision makers in the form of accumulation or reduction (of matter, energy or information).

On the other hand, as advocated by Vaz and Maldonado (2016), the dynamics of systems assume that there are several stocks within socio-techno-economic systems, influencing each other through their flows and dynamically, such statement refers to the third premise of the dynamics of systems: the processes of feedback or feedback, that is, every action or decision eventually produces a 
reaction of the system, changing, therefore, the state of the system under study, being that the sociotechno- Economic factors are formed by more than one feedback loop, both positive and negative.

Finally, the fourth and last premise of systems dynamics, for Vaz and Maldonado (2016), concerns the effect of the time lag, or delay, that is, the existence of a gap between decisions and the respective results generated by them, dynamically influencing the system's behavior.

The structure for the design of models in Systems Dynamics is composed of two main components, which are stocks and flows. Inventories refer to the model variables that are accumulated in the system and to the flows that are the decisions or policies of the system. These components can be organized in the form of cause and effect relationships, called balance or reinforcement feedback and are subject to time lags in the system under analysis (SIMONETTO et al, 2016). Ford (2009) defines Systems Dynamics as a method that combines flows and stocks in a computational structure to be simulated. In this work, Systems Dynamics was used because this method meets the main objective proposed here, which is to evaluate, in a future time horizon, the possibilities of financial benefits from the recycling of post-use cooking oil.

The system dynamics used in this document consists of five steps. Step I clearly defines the objectives to be achieved and the possible ways to resolve the model. This phase also includes the definition of the technical limitations of the system and the creation of the model. dynamic hypothesis that will be presented in section 3.1. In step II, the computational model will be built, with the intention of offering subsidies for the decision maker to identify its possible applications. In step III, the solution of the model will be presented through mathematical equations based on theoretical studies and dialogues with the interested parties. Having developed these three stages, the model developed in conjunction with his solution (Stage IV) will be implemented in the VENSIM-PLE software (Stage IV), for Andrade (2006) this stage must be controlled and monitored by a responsible team in order to detect and correct possible changes . solution values, which can cause some parts of the model to be reformulated. Finally, step $\vee$ will verify that the final objective has been achieved.

The next session will present the formulation of the dynamic hypothesis created for this article.

\subsection{Dynamic hypothesis formulation}

For Silva (2006), the dynamic hypothesis aims to work the problem theoretically, analyzing its behavior and observing which variables are part of the system. The objective of this step is to formulate a hypothesis that explains the dynamics as a consequence of the internal structure of the system through the interaction between the variables and the agents represented in the model. Thus, the dynamic hypothesis of the model of this paper is defined as: The variation of the financial impact generated by biodiesel production to replace mineral diesel. 


\section{Development of computer modeling}

The growing search for reduced exploitation of natural resources and the need to reduce the use of fossil fuels make public managers invest in new techniques for a more sustainable future. Increasingly, it is necessary to search for development processes that are supported by sustainability, thus avoiding the exhaustion of natural resources to meet the needs of the present without compromising the development of future generations.

In this sense, researchers such as Maia (2015) and Mendes (2015) present biodiesel as a solution to reduce the environmental impact generated by the excessive consumption of oil. Replacing fossil fuels by renewables is an international trend. Following this line of thought, we present the development of the simulation model, with its scenario simulation and assessment of the environmental and financial impacts caused by the interaction of model variables.

The model developed will be able to measure the financial impact related to the use of different portions of biodiesel in the collection, providing area managers with the benefits of using biodiesel in the collection. Another analysis carried out is the generation of the biodiesel itself by the company, through the use of the BIOBOT processor or the construction of a Plant by the company itself.

Costs related to the production of biodiesel through BIOBOT 20 take into account the total production process. An average of four liters of methanol costs $\$ 3.50$ and sodium hydroxide runs for $\$$ 0.50 . Vegetable oil is basically free, so a 15 -liter yield will end up totaling $\$ 1$ per gallon. Lower price than the current market, bringing to the market a new solution to reduce costs in the production of biodiesel, BIOBOT can help fuel the alternative transport revolution.

This study focuses on studying garbage collection in the central region of Rio Grande do Sul. The municipalities studied are presented in table 1.

\section{Table 1}

Population of the studied municipalities

$\begin{array}{cc}\text { County } & \text { № of inhabitants } \\ \text { Agudo } & 16.722 \\ \text { Cacequi } & 13.676 \\ \text { Faxinal do Soturno } & 6.672 \\ \text { Mata } & 5.111 \\ \text { Restinga Seca } & 15.849 \\ \text { São Francisco de Assis } & 19.254 \\ \text { São Martinho da Serra } & 3.201 \\ \text { TOTAL } & 80.485 \\ \text { Source: IBGE 2010. } & \end{array}$


The collection of solid waste from the region is performed by seven trucks, which have an average yield of 2.5 (two point five) kilometers per liter. Each municipality has a truck responsible for collection. Waste collection takes place differently through the number of inhabitants of each locality. The collections are usually held from Monday to Saturday for municipalities with 10,000 inhabitants or more. Municipalities with 5,000 to 10,000 inhabitants collect three times a week. In the municipality of São Martinho da Serra collection occurs only twice a week, considering that it has a population of less than 5,000 inhabitants.

The wastes are brought to Santa Maria city, where is the only licensed landfill in the region. The municipalities contemplated in this study do not have transhipment or tripleact. Table 2 shows the number of collections / weeks performed in each municipality, the mileage traveled to collect and send the waste to the landfill (in Santa Maria / RS), as well as the amount of fuel used in these routes.

Table 2

Monthly collection data

\begin{tabular}{|c|c|c|c|c|c|}
\hline County & № Collection & Send landfill & Spent Diesel & $\begin{array}{l}\text { Internal } \\
\text { Collection }\end{array}$ & Spent Diesel \\
\hline Agudo & 6 per week & $3403.2 \mathrm{~km}$ & 1361.28 liters & 500 km & 200 liters \\
\hline Cacequi & 6 per week & $5952 \mathrm{~km}$ & 2380.80 liters & $480 \mathrm{~km}$ & 192 liters \\
\hline Faxinal & 3 per week & $1406.4 \mathrm{~km}$ & 562.56 liters & $133.6 \mathrm{~km}$ & 53.44 liters \\
\hline Mata & 3 per week & 1992 km & 796.80 liters & 109.8 km & 43.92 liters \\
\hline Restinga Seca & 6 per week & $2827.2 \mathrm{~km}$ & 1130.88 liters & $493.4 \mathrm{~km}$ & 197.36 liters \\
\hline São Francisco & 6 per week & 6672 km & 2668.80 liters & 515.6 km & 206.24 liters \\
\hline São Martinho & 2 per week & 472 km & 188.80 liters & $42.8 \mathrm{~km}$ & 17.12 liters \\
\hline Total & $\mathrm{N} / \mathrm{C}$ & 19321.6 & 9089.92 & 2275.2 & 910.08 \\
\hline
\end{tabular}

Source: Authors (2019).

Data regarding the collection logistics were collected directly with a waste collection company in the central region, other data were collected from exploratory studies, the construction of the submodels generated by the interaction of the sought data will be exposed in the next session.

\subsection{Developed submodels}

The submodels were developed using the VENSIM-PLE software. Five types of variables were used. Stocks are state variables and can be repositories for accumulating or storing data. Auxiliary variables are components for performing algebraic operations, which process information about stocks and flows or represent sources of information external to the system. The flows, are action variables, 
they can increase or decrease the volume determined in the stock. It produces growth or reduction of stocks, movement of materials and information within the system. The shadow variable used is called "time", it allows the analysis of the proposed years. Finally, there are the connectors that represent the interrelationships between all the components, that is, it is these interconnections that connect the components that form the mathematical expression.

Current data on RSU collection were used in the central region of Rio Grande do Sul state, in order to verify the integration between all the variables that make up the model, as well as the results generated, since the outputs produced by the model were evaluated from actual data provided. In total, seven vehicles responsible for waste collection are used. Previously, a model for the financial impact analysis was designed, seeking to reinforce the justification for the application of the present study. After this analysis, three more submodels were generated that served as the central point for the article.

The "Biodiesel Generated" submodel is intended to model the behavior regarding the amount of "post-use" oil collected and, thus, to analyze the biodiesel generation capacity. Figure 1 represents the interaction between the submodel variables, consisting of a "Biodiesel Generated" stock variable that stores the amount (in liters) of biodiesel. The flow variables ("Total Oil", "OilRate") are the input variables of the stock variable and both receive their values from the auxiliary variables "Annual Oil", "TxOil". The passage of time in the model is represented by the shadow type variable called in the time model. In this case, it is connected to the variable "Annual Oil" in order to enter the variation of oil collected in the projected years.

Figure 1

"Biodiesel Generated" Submodel

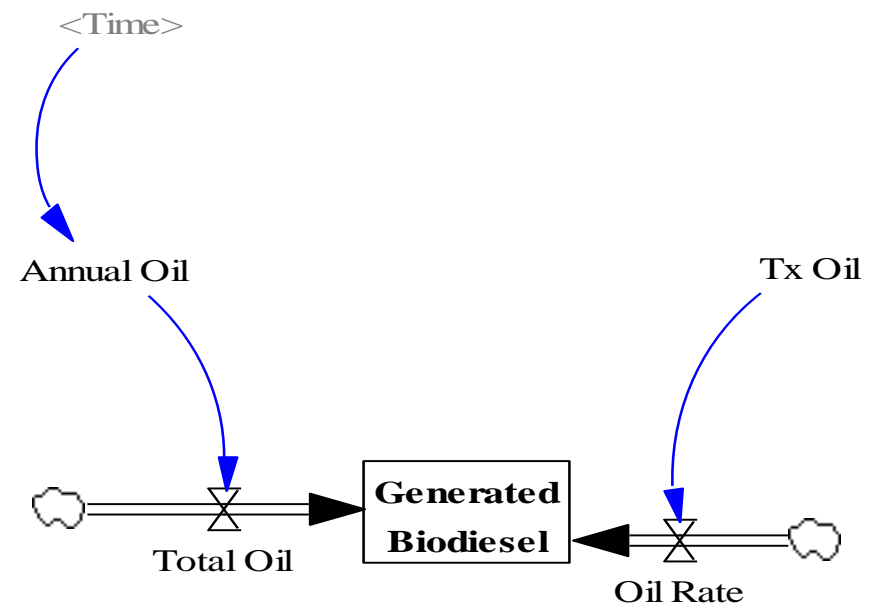

Source: Authors (2019). 
To analyze the behavior of the fuel used in the collection, the sub-model "Fuel" was generated. The submodel is composed of six auxiliary variables: "motoryield" - responsible for calculating the average engine performance of the seven collection vehicles, "Distancia" - stores the kilometers run on urban waste collection, "TxDiesel" and "TxBiodiesel" - attribute the rate of their respective fuels and serve as support to generate the exact amount of each fuel used, which are represented by the variables "Diesel" and "Biodiesel" respectively. Finally, the flow variable receives the value of the average engine efficiency ("Motor Yield"). Figure 2 presents the interaction of all variables exposed above.

\section{Figure 2}

\section{"Fuel Collect" Submodel}

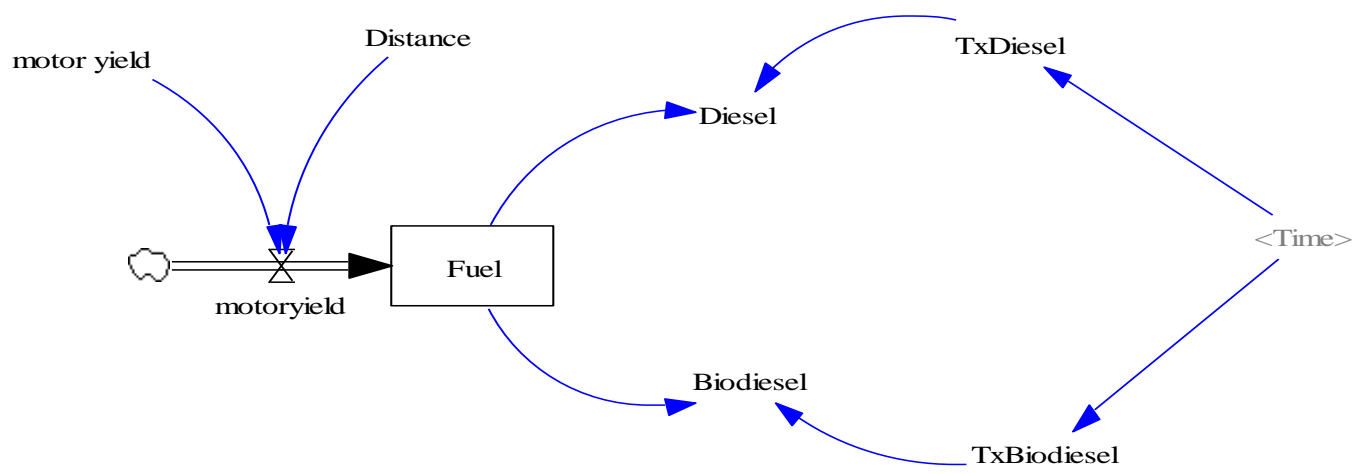

Source: Authors (2019).

Figure 3 presents the sub-model "CostOperation", used to analyze the financial impact related to the use of different portions of biodiesel in the collection, which allows to managers of the area to glimpse alternatives to using a renewable fuel, possibly cheaper than currently used. Another analysis was the generation of the biodiesel itself by the company, using the BIOBOT processor or the construction of a plant.

Auxiliary variables (Biodiesel Price, BiodieselS10 Price, Diesel Price and Diesel Price10) are responsible for storing the fuel cost over the 10 modeled years. The shadow Variables (Diesel and Biodiesel) combined with the auxiliary variables cited initially, are responsible for feeding the flow variables (Diesel cost, Diesel Cost S10, biodiesel Cost, biodiesel Cost S10).

The central variable of this submodel (Cost Operation) has the function of presenting the cost of the operation. Through the Vensim software, it was possible to visualize the cost variation in ten 
years, besides presenting the cost comparison for the biodiesel generation by the own company. This value is represented in the Usi / BIO variable. All these variables can be seen in Figure 3.

Figure 3

Cost Operation Submodel

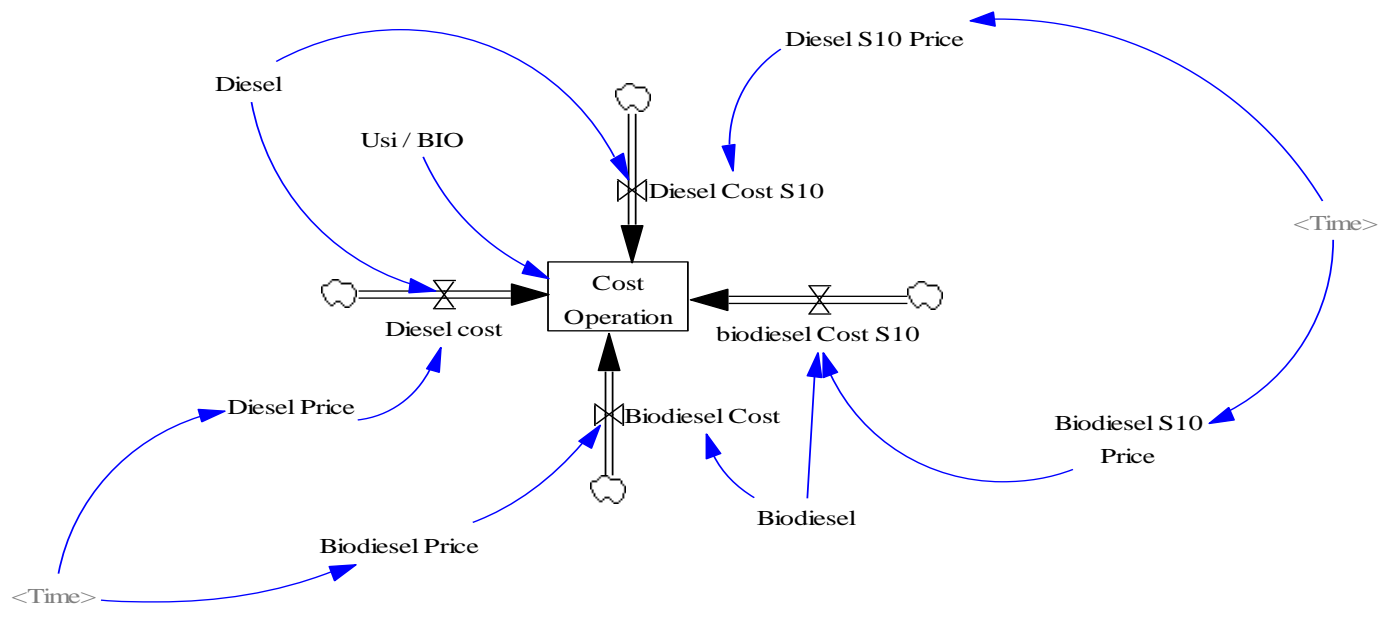

Source: Authors (2019).

Each submodel variable has a value and to adjust the logic of the submodels equations are generated, from which the result will be closer to the real system used as a parameter.

\section{Results}

The model was executed in the Vensim simulator (VENSIM, 2016) in a computer Pentium Core i5 processor and $8 \mathrm{~Gb}$ of RAM. The simulation execution time was in the order of millionths of seconds. The simulated time horizon in the experiment was 10 (ten) years; However, the setting of this variable is at the discretion of the designer / user, since it depends on the analysis to be performed. Nine scenarios were developed for the simulation.

The decisions, based on the results generated by the model, may involve the adoption of the proposed fuel (totally or partially), encouraging the achievement of a higher financial return. Decisions such as diesel purchase reduction and fossil fuel production reduction may also be suggested. Other analyzes and observations of interest to organizational managers, as long as they can be performed in the simulation model, may be performed, because the model was conceived seeking to simplify the user-model interaction, so that what-if analyzes are simple to perform. 
For the modeling developed in this study, nine scenarios were generated divided into 3 groups. The first group presents the simulation of the current collection and also the collection using ten and fifteen percent of biodiesel, as presented in Table 3. It is important to clarify that, in Brazil, according to the federal government convention, it is already used seven percent of biodiesel in the composition of commercial diesel, and this percentage is, therefore, already included in the current waste collection of the research sample.

The second group represents the scenarios using BIOBOT 20 for biodiesel generation, this tool is widely used by small producers to refine vegetable oils through transesterification. BIOBOT 20 has a production capacity of twenty liters per hour. The production process is divided into a few steps: initially, the oil is placed into the reaction chamber for heating and mixing. After this step, the oil is tested for the amount of free fatty acids and the right amount of sodium hydroxide catalyst needed. Finally, four liters of methanol are mixed until the fuel is ready (BIOBOT.ORG.UK, 2016).

The last set of scenarios presents the proposal for the creation of a small biodiesel plant by the own company. According to Vedana (2006), a project to build a small biodiesel plant is the same as that of a large plant, in both cases the maximum biodiesel yield per unit of oil should be sought, besides producing with high market quality. Through the machining it is possible to control the heating temperatures of vegetable oil, the reactive mixture can also be recirculated during the desired reaction time, thus acting directly on the transesterification process. Table 3 presents the data of the modeled scenarios.

The next analyzes performed describe the financial benefits that can be generated from the use of biodiesel to collect MSW, as well as its own production by the company. Initially, the collection was analyzed based on the purchase of fuel with different percentages of biodiesel. It is evident from Figure 4 that in the first 5 (five) simulated years, the difference is minimal between the sceneries. However, from the year 2022 the scenery "Garbage Collection B15" stands out in financial terms. In the year 2027, this scenery will have approximately four hundred and ninety-five thousand reais lower operating costs compared to the current collection scenery (Current Collection). 
Figure 4

Operation cost

\section{Operation Cost}

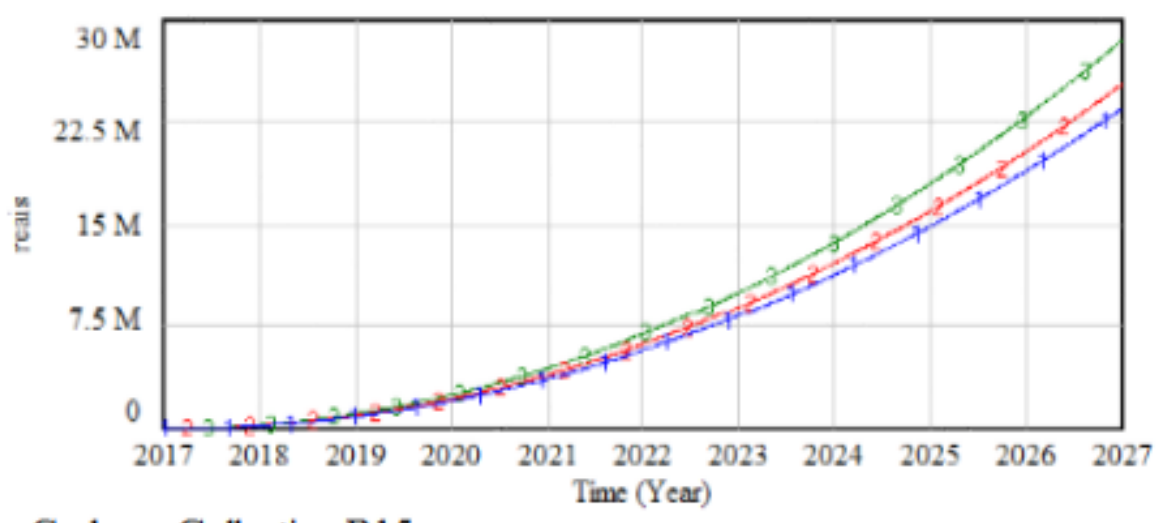

Garbage Collection B15

Garbage Collection B10

Current Collection

Source: Authors (2019).

In order to provide managers of the collection area for solid urban waste with subsidies on the possibility of producing their own biodiesel, three (3) scenarios were modeled with the acquisition of BIOBOT 20 by the company. Figure 5 presents the differences in the cost of operation for each scenery. As can be seen, the cost difference is insignificant until the middle of the year 2020. In ten (10) years of collection, the current collection scenery (Current Collection) accumulates a cost of approximately twenty-six million reais.

When comparing the current scenery with the "Coleta B15_BIOBOT" scenery there is a monthly reduction of sixty-two thousand reais. By 2017, this accumulated will represent savings equivalent to four million reais. If the option was not to increase the current concentration of biodiesel used in diesel for waste collection, the scenery "Current Collection_BIOBOT" was projected, which presented a cost reduction around one hundred and seventy-seven thousand reais per year, showing also a good possibility for the manager. 
Figure 5

BIOBOT Operation Cost 20

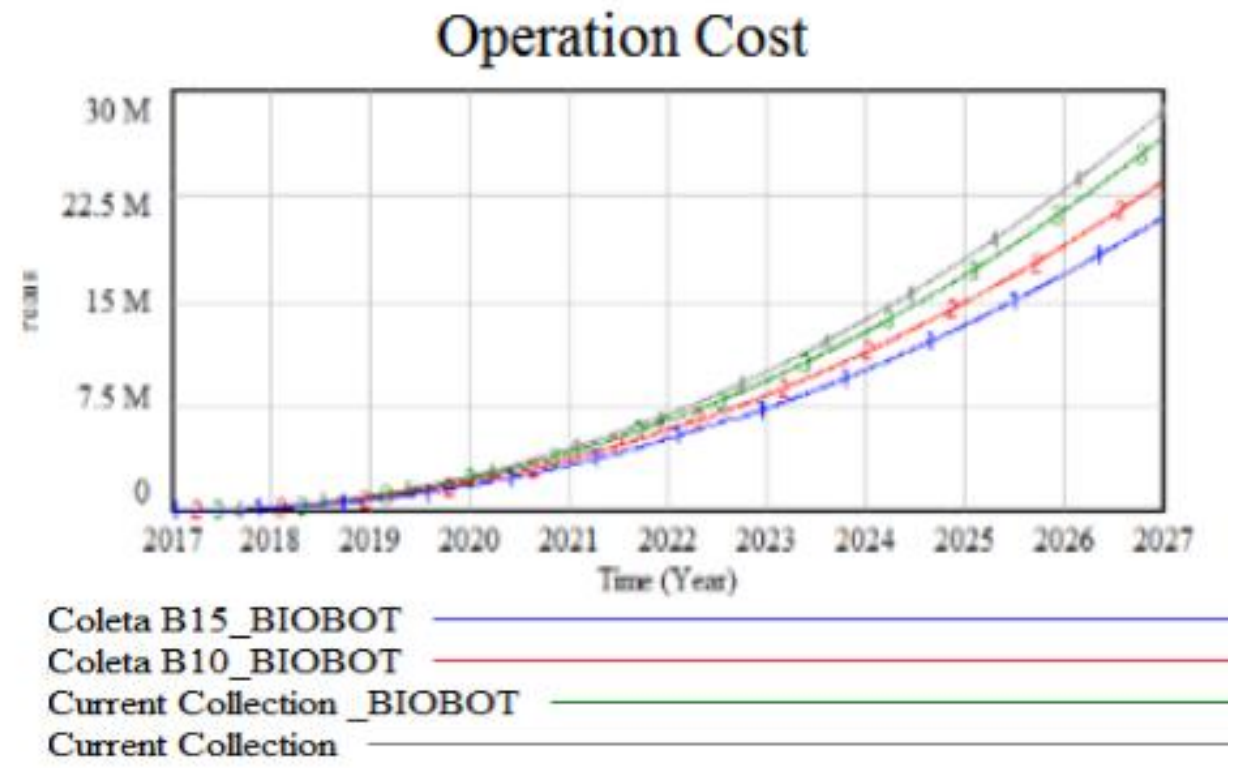

Source: Authors (2019).

Finally, the possibility of the company generating its own fuel through the creation of a small plant was analyzed. As can be seen in Figure 6, there are no significant differences until the year 2025. However, from this period, the "Collection B15_ USI" and "Collection B10_ USI" sceneries show considerable reduction in collection costs.

The scenery that has the lowest cost for waste collection, according to the simulations performed, is represented by "Current Collection_USIBIO", with an average reduction in the cost of operation of approximately fifty-two thousand reais per month - compared to the current collection. This value results in an accumulated reduction of up to six million reais in 2027. Compared to the second-best scenery ("Collection B10_USI") the reduction reaches two million reais in the ten modeled years. 
Figure 6

Plant Operation Cost

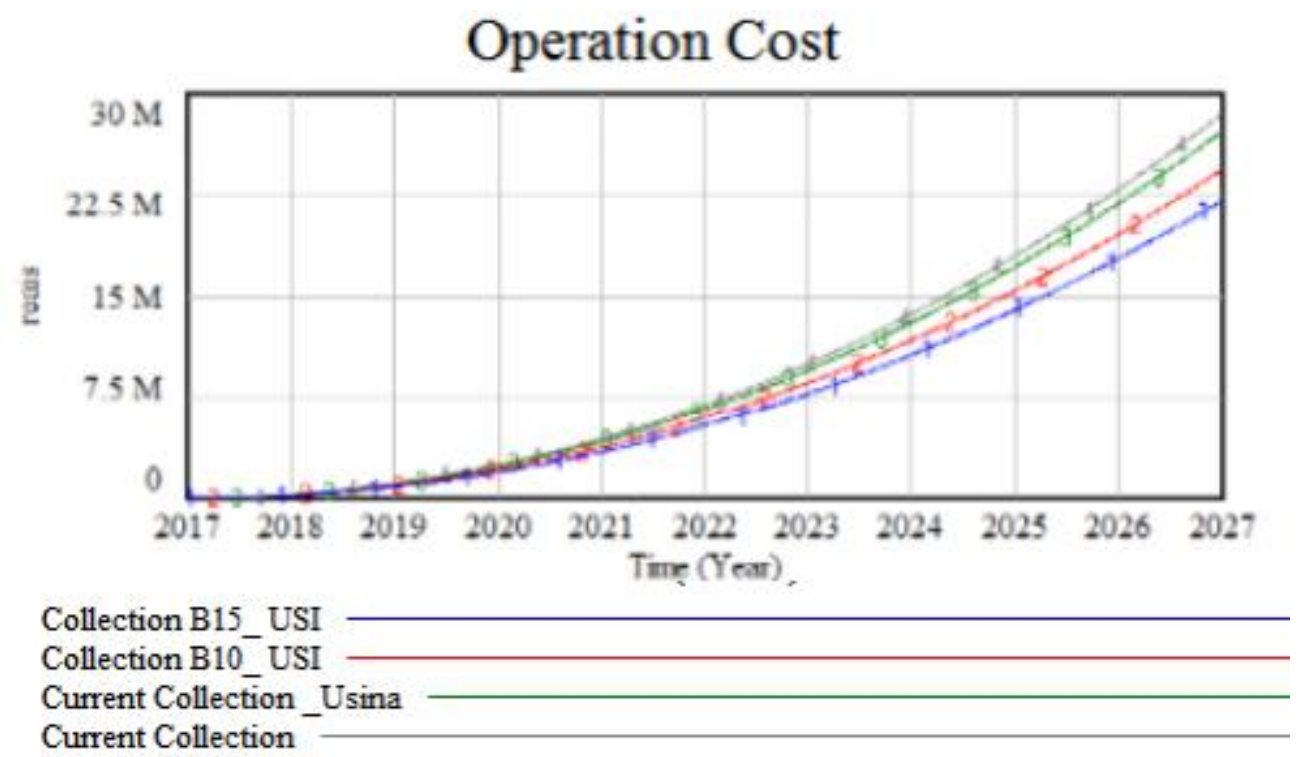

Source: Authors (2019).

On the other hand, the company may use the same percentage of biodiesel in the collection, since the scenery "Current Collection USIBIO" presents a monthly reduction of 10 (ten) thousand reais, accumulating one million and two hundred thousand reais at the end of the modeling performed. Using 15\% (fifteen percent) of biodiesel, the company will save about one thousand reais per day. Choosing to use $10 \%$ (ten percent) of biodiesel, the economy reaches up to four hundred thousand reais per year.

Thus, the results confirm the importance of developing public policies that consider both environmental and economic bias in the use of biofuels in the country's energy matrix. The simulations performed here demonstrate the feasibility of using "post-consumption" cooking oil as a raw material for biofuel generation, which, besides reducing the environmental impacts due to its improper disposal, is also a source of gains. Economical for its users.

\section{Final considerations}

This paper presented the proposal of a model for the use of cooking oil. The results presented were obtained through simulations made using Vensim software. However, it is already possible to state that the savings generated for a scenario of 10 years justify the application of the results generated by the model.

The main purpose of the present research was the development, verification and experimentation of submodels with the aim to evaluating scenery groups for the reuse of "post-use" 
cooking oil, transforming it into biodiesel, providing an idea of the extension of the cooking cycle life of this product. Biodiesel, according to Martins and Junior (2014), is technically viable as a fuel and possibly with advantages over petroleum-derived fuels.

The articulation of the research problem was obtained through two important aspects: Reference Modes and Time Horizon. Reference Modes: is to define the dynamic problem by looking at the behavioral history of key concepts and variables and predicting their behavior in the future. Time Horizon: Consider the past, present and future of the problem, thus showing how the problem is behaving and describing the symptoms. And, it will capture the effect of the problem in the future (SILVA, 2006).

Regarding the dynamic hypothesis, the objective was to work on the theory of the problem, analyzing its behavior and observing which variables are part of the system. The hypothesis presented in the research method was confirmed, because the use of biodiesel in the collection of urban solid waste had a financial impact, and may be viable for use by the private company studied.

For the development of the simulation model, we considered the concept that System Dynamics models are composed of stock variables, flow, both endogenous variables. One of the central purposes of the System Dynamics methodology is to have a model that can simulate real behavior. That is, the source of problems in a system is an inherent part of the developed model.

The System Dynamics methodology helped in the mapping of the developed system structures, seeking to examine their interrelationship in a broad context. Through the developed simulation, the applied dynamics intended to understand how the system in focus evolves over time and how changes in its parts affect its behavior. From this understanding, it was possible to diagnose and predict the system, as well as to simulate more scenarios in time.

Nine scenarios were generated, divided into three groups for model evaluation, using data collected through interviews with stakeholders and literature review. The results obtained are consistent with reality. The rates used were developed by the model designer for this study. It is noteworthy that the scenarios presented here were generated exclusively for this experiment. However, the model can be configured according to the needs of those who use it, that is, it is a reconfigurable and open model.

Regarding the results obtained and the scenarios evaluated, the best alternative is the use of BIOBOT 20, since it will bring greater financial impact on waste collection. Even if the company chooses not to increase the percentage of biodiesel in its fuel composition, its financial performance will be better using BІОВОТ 20. Based on the results generated by the simulation, managers will be able to define their fuel purchasing policies, taking into account consideration of financial sustainability in decision making. 
As suggestions for future papers, we encourage the use of the model in other geographic regions where urban waste is collected, as well as the evaluation of the social benefits generated by using "post-use" cooking oil as raw material for biodiesel production.

\section{Referências}

Abed, K. A., El Morsi, A. K., Sayed, M. M., El Shaib, A. A., \& Gad, M. S. (2018). Effect of waste cookingoil biodiesel on performance and exhaust emissions of a diesel engine. Egyptian journal of petroleum, 27(4), 985-989. DOI: https://doi.org/10.1016/j.ejpe.2018.02.008

Aboelazayem, O., Gadalla, M., \& Saha, B. (2019). Derivatisation-free characterisation and supercritical conversion of free fatty acids into biodiesel from high acid value waste cooking oil. Renewable Energy, 143, 77-90. DOI: https://doi.org/10.1016/j.renene.2019.04.106

Aghel, B., Mohadesi, M., Ansari, A., \& Maleki, M. (2019). Pilot-scale production of biodiesel from waste cooking oil using kettle limescale as a heterogeneous catalyst. Renewable Energy, 142, 207214. DOI: https://doi.org/10.1016/j.renene.2019.04.100

Ahmad, N., Javed, F., Awan, J. A., Ali, S., Fazal, T., Hafeez, A., \& Rehman, F. (2019). Biodiesel production intensification through microbubble mediated esterification. Fuel, 253, 25-31. DOI: https://doi.org/10.1016/j.fuel.2019.04.173

Amir-Heidari, P., Arneborg, L., Lindgren, J. F., Lindhe, A., Rosén, L., Raie, M., \& Hassellöv, I. M. (2019). A state-of-the-art model for spatial and stochastic oil spill risk assessment: A case study of oil spill from a shipwreck. Environment international, 126, 309-320. DOI: https://doi.org/10.1016/j.envint.2019.02.037

Andrade, A. L., Seleme, A., Rodrigues L. H. Souto, R (2006). Pensamento Sistêmico: caderno de campo: o desafio da mudança sustentada nas organizações e na sociedade. Porto Alegre, Bookman.

ANP. (2015). Agência Nacional do Petróleo, Gás Natural e Biocombustíveis. Boletim Anual de Preços 2015: preços do petróleo, gás natural e combustíveis nos mercados nacional e internacional/ Agência Nacional do Petróleo, Gás Natural e Biocombustíveis. Rio de Janeiro: ANP. 164 p.: il. color., gráficos, tabelas. Disponível em: https://www.gov.br/anp/pt-br/centrais-deconteudo/publicacoes/boletins-anp/boletim-anual-de-precos. Acesso em jan 2022.

Anwar, M., Rasul, M. G., Ashwath, N., \& Nabi, M. N. (2019). The potential of utilising papaya seed oil and stone fruit kernel oil as non-edible feedstock for biodiesel production in Australia-A review. Energy Reports, 5, 280-297. DOI: https://doi.org/10.1016/j.egyr.2019.02.007

Ashok, A., Cusack, M., Saderne, V., Krishnakumar, P. K., Rabaoui, L., Qurban, M. A., \& Agustí, S. (2019). Accelerated burial of petroleum hydrocarbons in Arabian Gulf blue carbon repositories. Science of the Total Environment, 669, 205-212. DOI: https://doi.org/10.1016/j.scitotenv.2019.01.437

Atabani, A. E., Shobana, S., Mohammed, M. N., Uğuz, G., Kumar, G., Arvindnarayan, S., \& Ala'a, H. (2019). Integrated valorization of waste cooking oil and spent coffee grounds for biodiesel production: Blending with higher alcohols, FT-IR, TGA, DSC and NMR characterizations. Fuel, 244, 419-430. DOI: https://doi.org/10.1016/j.fuel.2019.01.169 
Bechet, Q., Shilton, A., Fringer, O. B., Munoz, R., \& Guieysse, B. (2010). Mechanistic modeling of broth temperature in outdoor photobioreactors. Environmental science \& technology, 44(6), 21972203. DOI: https://doi.org/10.1021/es903214u

Bhatia, S. K., Bhatia, R. K., Jeon, J. M., Kumar, G., \& Yang, Y. H. (2019). Carbon dioxide capture and bioenergy production using biological system-A review. Renewable and sustainable energy reviews, 110, 143-158. DOI: https://doi.org/10.1016/j.rser.2019.04.070

Bórawski, P., Bełdycka-Bórawska, A., Szymańska, E. J., Jankowski, K. J., Dubis, B., \& Dunn, J. W. (2019). Development of renewable energy sources market and biofuels in The European Union. Journal of cleaner production, 228, 467-484. DOI: https://doi.org/10.1016/j.jclepro.2019.04.242

BRASIL. (2008). Lei no 11.116, de 18 de maio de 2008. Diário Oficial da República Federativa do Brasil. Poder Executivo, Brasília, DF, 19 mai. 2008.

Chen, H., \& Chen, W. (2019). Potential impacts of coal substitution policy on regional air pollutants and carbon emission reductions for China's building sector during the 13th Five-Year Plan period. Energy Policy, 131, 281-294. DOI: https://doi.org/10.1016/j.enpol.2019.04.047

Chrysikou, L. P., Dagonikou, V., Dimitriadis, A., \& Bezergianni, S. (2019). Waste cooking oils exploitation targeting EU 2020 diesel fuel production: Environmental and economic benefits. Journal of Cleaner Production, 219, 566-575. DOI: https://doi.org/10.1016/j.jclepro.2019.01.211

Cruz, R. P., Ferreira, F. B., \& Rodrigues, F. D. Á. (2017). Simulação e análise econômica da produção de biodiesel a partir de óleo de macaúba. DOI: 10.18540/2446941603032017533.

Demirbas, M. F. (2009). Biorefineries for biofuel upgrading: a critical review. Applied energy, 86, S151S161. DOI: https://doi.org/10.1016/j.apenergy.2009.04.043

Dimitriou, P., Tsujimura, T., \& Suzuki, Y. (2019). Adopting biodiesel as an indirect way to reduce the NOx emission of a hydrogen fumigated dual-fuel engine. Fuel, 244, 324-334. DOI: https://doi.org/10.1016/j.fuel.2019.02.010

Donato, V. (2008). Logística Verde. Rio de Janeiro: Ciência Moderna Ltda, 256 p.

Dyson, B., \& Chang, N. B. (2005). Forecasting municipal solid waste generation in a fast-growing urban region with system dynamics modeling. Waste management, 25(7), 669-679. DOI: https://doi.org/10.1016/j.wasman.2004.10.005

Encinar, J. M., González, J. F., \& Rodríguez-Reinares, A. (2007). Ethanolysis of used frying oil. Biodiesel preparation and characterization. Fuel processing technology, 88(5), 513-522. DOI: https://doi.org/10.1016/j.fuproc.2007.01.002

Fazal, M. A., Haseeb, A. S. M. A., \& Masjuki, H. H. (2011). Biodiesel feasibility study: an evaluation of material compatibility; performance; emission and engine durability. Renewable and sustainable energy reviews, 15(2), 1314-1324. DOI: https://doi.org/10.1016/j.rser.2010.10.004

Felizardo, P., Correia, M. J. N., Raposo, I., Mendes, J. F., Berkemeier, R., \& Bordado, J. M. (2006). Production of biodiesel from waste frying oils. Waste management, 26(5), 487-494. DOI: https://doi.org/10.1016/j.wasman.2005.02.025 
Ferronato, N., Ragazzi, M., Portillo, M. A. G., Lizarazu, E. G. G., Viotti, P., \& Torretta, V. (2019). How to improve recycling rate in developing big cities: An integrated approach for assessing municipal solid waste collection and treatment scenarios. Environmental Development, 29, 94-110. DOI: https://doi.org/10.1016/j.envdev.2019.01.002

Ford, A. (2009). Modeling theen vironment, Second Edition. Island Press.

Hatzisymeon, M., Kamenopoulos, S., \& Tsoutsos, T. (2019). Risk assessment of the life-cycle of the Used Cooking Oil-to-biodiesel supply chain. Journal of Cleaner Production, 217, 836-843. DOI: https://doi.org/10.1016/j.jclepro.2019.01.088

Kannengiesser, J., Sakaguchi-Söder, K., Mrukwia, T., Jager, J., \& Schebek, L. (2016). Extraction of medium chain fatty acids from organic municipal waste and subsequent production of biobased fuels. Waste management, 47, 78-83. DOI: https://doi.org/10.1016/j.wasman.2015.05.030

Kum, V., Sharp, A., \& Harnpornchai, N. (2005, July). A system dynamics study of solid waste recovery policies in Phnom Penh City. In The 23rd International Conference of the System Dynamics Society, Boston. Proceedings... Boston: SDS. Disponível em: http://www.dinamica-desistemas.com/paper/31_23.pdf. Acesso em Jan 2021.

Kumar, D., \& Scheiter, S. (2019). Biome diversity in South Asia-How can we improve vegetation models to understand global change impact at regional level? Science of the Total Environment, 671, 1001-1016. DOI: https://doi.org/10.1016/j.scitotenv.2019.03.251

Lam, M. K., Lee, K. T., \& Mohamed, A. R. (2010). Homogeneous, heterogeneous and enzymatic catalysis for transesterification of high free fatty acid oil (waste cooking oil) to biodiesel: a review. Biotechnology advances, 28(4), 500-518. DOI: https://doi.org/10.1016/j.biotechadv.2010.03.002

Law, A.M. (2015). Simulation Modeling and Analysis. 5ed., McGraw-Hill.

Leite, R. C. D. C., \& Leal, R. L. V. M. (2007). O biocombustível no Brasil. Revista Novos Estudos CEBRAP, (78), 15-21. Disponível em: https://www.scielo.br/j/nec/a/8FyQn8jGsFVfzGZyst4CWbc/?lang=pt. Acesso em Jan 2021.

Lu, Y., Wang, Q. G., Zhang, X., Qian, Y., \& Qian, X. (2019). China's black carbon emission from fossil fuel consumption in 2015, 2020, and 2030. Atmospheric Environment, 212, 201-207. DOI: https://doi.org/10.1016/j.atmosenv.2019.04.032

Madheshiya, A. K., \& Vedrtnam, A. (2018). Energy-exergy analysis of biodiesel fuels produced from waste cooking oil and mustard oil. Fuel, 214, 386-408. DOl: https://doi.org/10.1016/j.fuel.2017.11.060

Maia, R.R.S. (2015). Biodiesel no Brasil: análise de custo-benefício. Editora Appris, Curitiba, Paraná.

Mandotra, S. K., Ahluwalia, A. S., \& Ramteke, P. W. (2019). Production of high-quality biodiesel by Scenedesmus abundans. In The Role of Microalgae in Wastewater Treatment (pp. 189-198). Springer, Singapore. DOI: https://doi.org/10.1007/978-981-13-1586-2_14

Marcos-Martinez, R., Bryan, B. A., Schwabe, K. A., Connor, J. D., Law, E. A., Nolan, M., \& Sánchez, J. J. (2019). Projected social costs of $\mathrm{CO} 2$ emissions from forest losses far exceed the 
sequestration benefits of forest gains under global change. Ecosystem services, 37, 100935.

DOI: https://doi.org/10.1016/j.ecoser.2019.100935

Martins, C., \& Andrade Jr, P. P. (2014). Produção de biodiesel no Brasil: Estratégia de sustentabilidade social, econômica e ambiental. Sustainable Business International Journal, (40). DOI: https://doi.org/10.22409/sbijounal2014.i40.a10224

Mendes, P.A.S. (2015). Sustentabilidade na produção e uso do biodiesel. Curitiba. Appris.

Miranda, A. C., da Silva Filho, S. C., Tambourgi, E. B., CurveloSantana, J. C., Vanalle, R. M., \& Guerhardt, F. (2018). Analysis of the costs and logistics of biodiesel production from used cooking oil in the metropolitan region of Campinas (Brazil). Renewable and Sustainable Energy Reviews, 88, 373-379. DOI: https://doi.org/10.1016/j.rser.2018.02.028

Mittelbach, M., \& Gangl, S. (2001). Long storage stability of biodiesel made from rapeseed and used frying oil. Journal of the American Oil Chemists' Society, 78(6), 573-577. DOI: https://doi.org/10.1007/s11746-001-0306-z

Mohadesi, M., Aghel, B., Maleki, M., \& Ansari, A. (2019). Production of biodiesel from waste cooking oil using a homogeneous catalyst: Study of semi-industrial pilot of microreactor. Renewable Energy, 136, 677-682. DOI: https://doi.org/10.1016/j.renene.2019.01.039

Nabi, M. N., Rasul, M. G., Anwar, M., \& Mullins, B. J. (2019). Energy, exergy, performance, emission and combustion characteristics of diesel engine using new series of non-edible biodiesels. Renewable energy, 140, 647-657. DOI: https://doi.org/10.1016/j.renene.2019.03.066

Nijmeijer, A., Lauri, P. É., Harmand, J. M., \& Saj, S. (2019). Carbon dynamics in cocoa agroforestry systems in Central Cameroon: afforestation of savannah as a sequestration opportunity. Agroforestry Systems, 93(3), 851-868. DOI: https://doi.org/10.1007/s10457-017-0182-6

Ranjan, A., Dawn, S. S., Jayaprabakar, J., Nirmala, N., Saikiran, K., \& Sriram, S. S. (2018). Experimental investigation on effect of $\mathrm{MgO}$ nanoparticles on cold flow properties, performance, emission and combustion characteristics of waste cooking oil biodiesel. Fuel, 220, 780-791. DOI: https://doi.org/10.1016/j.fuel.2018.02.057

Reis, M. P. F. P.; Ellwanger, R. M.; Fleck, E. (2007). Destination of frying oils. Proceedings of the Brazilian Congress on Sanitary and Environmental Engineering, ABES.

Rodrigues, G. O., de Oliveira Simonetto, E., Ravanello, F., Beltrame, G., \& Motke, F. D. (2016). SUSTENTABILIDADE NO USO DO BIODIESEL: modelagem computacional baseada em dinâmica de sistemas. Revista da Universidade Vale do Rio Verde, 14(1), 930-946. DOI: http://dx.doi.org/10.5892/ruvrd.v14i1.2749

Sahar, S. S., Iqbal, J., Ullah, I., Bhatti, H. N., Nouren, S., Habibur, R., \& Iqbal, M. (2018). Biodiesel production from waste cooking oil: an efficient technique to convert waste into biodiesel. Sustain Cities Soc 41: 220-226. DOI: https://doi.org/10.1016/j.scs.2018.05.037

Shafiee, S., \& Topal, E. (2009). When will fossil fuel reserves be diminished? Energy policy, 37(1), 181189. DOI: 10.1016/j.enpol.2008.08.016. DOI: https://doi.org/10.1016/j.enpol.2008.08.016

Shimabukuro, Y. E., Arai, E., Duarte, V., Jorge, A., Santos, E. G. D., Gasparini, K. A. C., \& Dutra, A. C. (2019). Monitoring deforestation and forest degradation using multi-temporal fraction images 
derived from Landsat sensor data in the Brazilian Amazon. International Journal of Remote Sensing, 40(14), 5475-5496. DOI: https://doi.org/10.1080/01431161.2019.1579943

Shomal, R., Hisham, H., Mlhem, A., Hassan, R., \& Al-Zuhair, S. (2019). Simultaneous extractionreaction process for biodiesel production from microalgae. Energy Reports, 5, 37-40. DOI: https://doi.org/10.1016/j.egyr.2018.11.003

Santos, M. X., \& da Silva, J. G. F. (2016). Aproveitamento do óleo residual de fritura na produção de biodiesel Utilization of residual frying oil in biodiesel production. REMEA-Revista Eletrônica do Mestrado em Educação Ambiental, 33(1), 299-306. DOI: https://doi.org/10.14295/remea.v33i1.5111

Silva, E. C. P. (2006). O impacto da gestão do tamanho da força policial na taxa de violência em Curitiba: Uma abordagem qualitativa sob o referencial da dinâmica de sistemas. 2006 (Doctoral dissertation, Dissertação (Mestrado em Engenharia de Produção e Sistemas) Pontifícia Universidade Católica do Paraná). Disponível em: https://www.biblioteca.pucpr.br/tede/tde_arquivos/9/TDE-2007-01-30T081953Z490/Publico/Elaine\%20PPGEPS.pdf Acesso em Jan 2021.

Simonetto, E. D. O. (2014). Simulation computer to evaluate scenarios of solid waste-an approach using systems dynamics. International Journal of Environment and Sustainable Development 8 , 13(4), 339-353. Disponível em: https://www.inderscienceonline.com/doi/abs/10.1504/IJESD.2014.064960. Acesso em Jan 2021.

Sufian, M. A., \& Bala, B. K. (2007). Modeling of urban solid waste management system: The case of Dhaka city. Waste Management, 27(7), 858-868. DOI: https://doi.org/10.1016/j.wasman.2006.04.011

Talebian-Kiakalaieh, A., Amin, N. A. S., \& Mazaheri, H. (2013). A review on novel processes of biodiesel production from waste cooking oil. Applied Energy, 104, 683-710. DOI: https://doi.org/10.1016/j.apenergy.2012.11.061

Tan, Y. H., Abdullah, M. O., Kansedo, J., Mubarak, N. M., San Chan, Y., \& Nolasco-Hipolito, C. (2019). Biodiesel production from used cooking oil using green solid catalyst derived from calcined fusion waste chicken and fish bones. Renewable energy, 139, 696-706. DOI: https://doi.org/10.1016/j.renene.2019.02.110

Tavares, B.M.; Da Silva. S.R.R. (2008). Biodiesel: fonte de combustível limpo atuando como rica contribuição estratégica, social e ecológica na região de Lins, Monografia apresentada ao Centro Universitário Católico Salesiano Auxilium - UNISALESIANO, Lins-SP, para graduação em Administração.

Vedana. U, Usinas demais, produção de menos (2008). Disponível em: https://www.biodieselbr.com/revista/003/coluna-univaldo.htm. Acesso out de 2020.

Velmurugan, R., Mayakrishnan, J., Induja, S., Raja, S., Nandagopal, S., \& Sathyamurthy, R. (2019). Comprehensive study on the effect of $\mathrm{CuO}$ nano fluids prepared using one-step chemical synthesis method on the behavior of waste cooking oil biodiesel in compression ignition engine. Journal of Thermal Science and Engineering Applications, 11(4). DOI: https://doi.org/10.1115/1.4041878 
Vensim - Ventana Simulations (2016), Vensim simulation software. Disponível em: http://www.vensim.com, 2014. Acessado em Dez. 2021.

Vensim, Manual Vensim-PLE, Disponível em: http://www.vensim.com, 2004. Acessado em Dez. 2021.

Vidmantas, J. B., Tirlone, C. A., Bigatão, B. A., \& França-Júnior, J. D. M. (2010). Estudo do destino de resíduos oleosos em estabelecimentos de comida rápida situados em shopping na cidade de Dourados/MS. III Simpósio Intercâmbio Brasil/Japão em Sustentabilidade: Um Desafio da Humanidade, Campo Grande, Mato Grosso.

Ye, X., Chen, B., Li, P., Jing, L., \& Zeng, G. (2019). A simulation-based multi-agent particle swarm optimization approach for supporting dynamic decision making in marine oil spill responses. Ocean \& Coastal Management, 172, 128-136. DOI: https://doi.org/10.1016/j.ocecoaman.2019.02.003

Zailani, S., Iranmanesh, M., Sean Hyun, S., \& Ali, M. H. (2019). Applying the theory of consumption values to explain drivers' willingness to pay for biofuels. Sustainability, 11(3), 668. Disponível em: https://www.mdpi.com/2071-1050/11/3/668. Acesso em Jan 2021.

Zhang, L., \& Kong, S. C. (2010). Vaporization modeling of petroleum-biofuel drops using a hybrid multi-component approach. Combustion and Flame, 157(11), 2165-2174. DOI: https://doi.org/10.1016/j.combustflame.2010.05.011

Zhao, F., Liu, F., Liu, Z., \& Hao, H. (2019). The correlated impacts of fuel consumption improvements and vehicle electrification on vehicle greenhouse gas emissions in China. Journal of Cleaner Production, 207, 702-716. DOI: https://doi.org/10.1016/j.jclepro.2018.10.046 